Kymbat Bekenayeva teacher

International Scientific Journal Theoretical \& Applied Science

p-ISSN: 2308-4944 (print) e-ISSN: 2409-0085 (online)

Year: $2014 \quad$ Issue: 12 Volume: 20

Published: $30.12 .2014 \quad$ http://www.T-Science.org

SECTION 22. Policy. Innovations. Theory, practice and methods.
Kazakh National Medical University named after S.D.Asfendiyarov, Kazakhstan kymbat.bekenayeva@mail.ru Aliya Sharizatovna Barakova teacher

Kazakh National Medical University named after S.D.Asfendiyarov, Kazakhstan Balia_79@mail.ru Sholpan Erlepesovna Zhusipbekova teacher Kazakh National Medical University named after S.D.Asfendiyarov, Kazakhstan Sholpan_80Aeka@mail.ru

\title{
INFORMATION AND COMMUNICATION TECHNOLOGIES IN GOVERNMENT
}

\begin{abstract}
One of the main elements of creation of modern civil society and open public administration in a number of the developed countries is the system of the electronic government. Modern information society is closely connected with the electronic government, E-government, which carries out important functions on regulation of information relations between the state both its citizens and the organizations. In this article definitions of information and communication technologies, the main directions and mechanisms of the electronic government are given.

Key words: information and communication technologies, e-government, information society, electronic portals, e-services, citizens.

Language: English

Citation: Bekenayeva K, Barakova AS, Zhusipbekova SE (2014) INFORMATION AND COMMUNICATION TECHNOLOGIES IN GOVERNMENT. ISJ Theoretical \& Applied Science 12 (20): $22-26$. doi: http://dx.doi.org/10.15863/TAS.2014.12.20.6
\end{abstract}

Information and Communication Technologies (ICT) - a set of methods, processes, software and hardware, integrated with the aim of collecting, processing, storage, distribution, display and use of information in the interests of its members.

Development and utilization of information and communication technologies (ICT) is a global trend of world development and scientific and technological revolution of recent decades. Use of ICT is crucial for improving the competitiveness of the economy, empower its integration into the world economy, increasing the efficiency of public administration and local government.

Experts believe that the introduction of information and communication technologies (ICT) in public administration will accelerate the development of the economy, reduce the cost of bureaucratic procedures, improve efficiency and productivity of government departments, empowering people in civil society by improving access to different kinds of information, a more transparent public services, reduce bureaucratic barriers.
Modern information and communication technologies provide the ability to create egovernment based on the interests of citizens.

History of e-government is in parallel with the development of information technology. "Egovernment" refers to the use of information technology, particularly the Internet, as the most affordable means of electronic communication between public authorities, citizens and private business.

The term "e-Government" implies an organization of public administration based on the electronic processing, and dissemination of information and provision of services of all branches of power to all categories of citizens and the private sector by electronic means (Internet, phone, fax, access centers, wireless communication devices and other systems).

Concept of governance characteristic of the information society based on the capabilities of information and telecommunication technologies and values of an open civil society. Characterized oriented to the needs of citizens, economic efficiency, openness to public scrutiny and initiatives .One of the most effective ways to fight corruption 
and bureaucracy, as well as ensuring transparency in official structures.

Definition of e-government experts are built on different principles. Some authors prefer descriptive definition - exactly what the transformations taking place within society and its structures through the introduction of e-government. Other elected applied aspect of e-government, and just list the different application of certain of its instruments. There are technical definitions that emphasize purely on used technological solutions and specific software products. As well as determining the economic efficiency -maximizing government.

Each principle is true, since it shows a certain aspect of the functioning of e-government. Nevertheless, erroneous will not be taken into account, lower their particular. Consider from this point of view are just some of the interpretations of the term.

\section{So, e-government is defined as follows:}

1) Organization of governance based on the electronic processing, and dissemination of information, the provision of government services of all branches of power to all categories of citizens ( pensioners, workers, businessmen, civil servants, etc.) by electronic means, by the same means of informing citizens about the work government agencies.

2) Metaphor, which means the information interaction of public authorities and society using information and telecommunication technologies.

3) Automated public services whose main functions are: to provide free public access to all relevant public information, the collection of taxes, vehicle registration and patents, issuing the necessary information, the conclusion and execution of supply of needed materials to the state apparatus and equipment. This can lead to lower costs and save taxpayers' money for the maintenance and funding of the state apparatus, increased openness and transparency of government.

However, each of these definitions is egovernment more like a regular application solution, a way to modernization of existing structures and relationships, rather than as an independent idea of integrated transformation of the very principles of the organization of government. The assessment method of e-government, its capabilities, elected experts in the field of information technology, public administration, social processes, economic development, and spread of the direct executors government officials.

The system of "electronic government" there are three main components:

- Component oriented on citizens: Interaction between government and citizens (in international terminology G2C). Prompt receipt of services, ease of use, and easy access to public services. Open to any citizen becomes agency, any service or information. Personal data is accessible only to their "owner" and the relevant keys, several public services (health, social, certain information - tax, etc.). "Privilege shop" - the right to authorize whether to prohibit certain activities of citizens to register or not to register the marriage, change the names - G2C module makes contact. Moreover, automated service that is independent of the identity of the official, the statements in question.

- Component oriented on private sector interaction between government and the private sector (in international terminology G2B), eliminates the need for paper documents the interaction between themselves and thus accelerate the process of collecting and processing relevant information. Ultimately, state agencies with partners in the face of commercial organizations will be able to provide its channels to create an integrated system of service delivery. Reduced costs for public authorities, through better use of technology, operates an open and transparent public procurement system. Module "government - business" not only simplifies the implementation of standard procedures like filling returns or credits registration. Its main feature - at the expense of simplicity, speed up and automate the process as much as possible to encourage people to create their own business. Since it is private capital is the driving force behind the development of the country, not only economic but also social, cultural, technological and scientific development.

- Component oriented on public administration: Interaction between public authorities (in international terminology G2G), which allows using ICTs to establish internal and external communications between the government and implement their interaction that will restructure their activities and to provide an integrated, rather than piecemeal provision of services. This will reduce costs and improve efficiency, avoiding delays and increasing the motivation of employees. This will allow for the restructuring of internal processes with the use of well-established and widely used methods and tools.

However, each of these three modules creates favorable conditions for social passivity citizen groups, community. Barriers removed, overcome bureaucratic red tape, do not stand in line, collect the papers, run the chain of command or wait for a decision. G2C module provides easy access to the desired page structure through a common portal module G2B allows you to simply issue permits and licenses, credits and incentives, almost without wasting time filling out forms, as applies for the necessary personal data to resources module G2G. Ideal conditions for the closure of each in their own world, equipped with an electronic interface to address current issues.

Disappears and the influence of other modules (in particular, the most significant - B2B (business to 
business) B2C (business to citizens), $\mathrm{C} 2 \mathrm{~B}$ (citizens to business). Modules is not e-government and information society - social formation based on knowledge, abilities to human creativity and the possibilities of information and telecommunication technologies.

In some states, citizens have the opportunity through the Internet, for example, to register vehicles, renew their driver's license, and pay taxes without physically visiting institutions and idling in long queues. This can lead to an increase in the degree of involvement of citizens in policy and management process. Is a weakening of the position of the bureaucracy in society, significantly reduced the risk of corruption, turnover record keeping documentation becomes a common feature of the state machine. It is believed that the last stage of the transition of traditional e- government is defined by the existence of a single web portal where you can find any government information. All government services are possible in the online mode and all administrative activities carried out by electronic means, i.e. paperless. Experts believe this step is almost unattainable. About the desire to achieve it said only two countries (UK and Singapore).

Introduction of "electronic government" is a complex organizational, economic, technological and social process that requires considerable financial costs and administrative effort. Success in this case depends on the correct strategy and tactics at every stage of implementation, rational organization, coordination and cooperation of all stakeholders - the legislative, executive and judicial authorities at all levels, the private sector, the public, educational organizations and citizens. Furthermore, to solve a set of interrelated political, legal, organizational and technological issues, identify funding sources, train staff.

\section{Implementation of e-government}

The problem of e-government and the consequences of this process - the project road. It requires investment not only in the computerization of government departments and training of civil servants. Large funds are laid on building government network, creation of information and telecommunication infrastructure, education and propaganda activities, the introduction of courses in schools, universities, employment centers, clubs and other institutions, to cover all segments of the population, to provide them with equal opportunities of use of electronic government. Also included is the cost items, training, custom software development, maintenance of structures in good condition, network security, the development of the regulatory framework and the training of judges appropriate qualifications, ensuring computer literacy of civil servants of various departments (especially the Ministry of Interior, Ministry of Justice etc.).
- With redefine the regulatory framework in electronic form you will get access to all orders, decrees and laws to defend their rights, based on the specific facts of violations. Those who have more income and cannot afford a computer and internet at home - will contact government services from home. Those who have access to the Internet from work, also elect the opportunity to decide their own affairs during a lunch break or after office hours from their desks. Still a certain percentage of citizens (mostly younger) go to Internet cafes to paying rid of the queue in the official establishment - and to release all of his own. When distributing public access points (pods) percentage of "electronic citizens" still increase. As a result, you get virtually free access to services and foster public authorities - officials will have the time and opportunity to pay more attention to you, for you to spend more time to explain in detail your rights, find out exactly what you need. With less impact clerks and secretaries will be more polite, heads - more accessible. You and your needs become more visible to the state, more important for its employees.

- For e-government civil servant - a handy thing that makes your work more creative and less routine, although it requires more skill and more responsibility. Employee role in e-government is more and more important as it ceases to be just a $\operatorname{cog}$ in the state machine.

- For e-government policies - is the ability to keep society and print about its activities and not disappear from the information field in the period between election campaigns. Policymaker's name will not be forgotten, and his achievements at any point can be argued, referring to the appropriate electronic resource where everything is given in detail. E-government is the ability to control "online" activities of any authorities or officials. It means a specific and thorough criticism, reasoned and timely, and in addition, the prospect of egovernment is a digital democracy - the most effective way of all existing support contact with the electorate and the preservation of the social base of the political movement or structure.

- The main advantage of e-government - its focus on the citizen, to the client. Electronic government finally puts the state, its agencies and employees of the place - the place that was given to them and in the model of civil society.

The four pillars of successful implementation of e-government in any country:

1. Creation of electronic portals;

2. Creating computers available to the public;

3. Creating conditions for the emergence of affordable Internet;

4. Care for computer literacy people.

Creating government portals is an effective way to organize, search, and giving people the 
information they want to receive or that they need to complete their tasks quickly and easily.

Technology term "portal" means to create userfriendly website, "SSO", the principle of which is that if you want a solution to a problem or meet any needs citizens have quick and easy access to all relevant information, all the necessary resources and interactive services.

Consider the economic impact of the creation of state portals.

1. Reducing the cost of paper and printing, saving areas (storage of electronic documents requires an order of magnitude smaller space $\neg$ ), lower costs for telephone and mail (documents can be placed the Internet or sent by e-mail).

2. Reduces the time needed to perform common operations, which include search, training certificates, reports, preparation of solutions, telephone calls, receiving visitors, use - board errors and analysis of conflict situations ( for employees associated with the reception of citizens, can reach $75 \%$ of the working time).

3. Budget cuts to carry out activities related to official notices must spread standard materials, changes in the forms of documents, advocacy and other PR- activities aimed at enabling citizens support decisions and positions of power.

Strengthening the implementation of the state -governmental procurement

Above consists in increasing the efficiency of institutions, which can also be expressed in the increasing number of applications processed, improving tax collection, etc.

Reservations can have the following hardware and software architecture (in the general case it is the same as that of the large enterprise portal $\neg$ entities):

- cluster of computers (or a computer) with constant, high-speed Internet connection;

- a multiuser, multitasking server operating system;

- Web server;

- Application Server with embedded business logic elements;

- DBMS to store documents and other information portal;

- content management system that allows employees who are not specialists in information technology, to publish documents quickly and accurately, and to maintain their relevance; Egovernment portal of the Republic Kazakhstan (www.e.gov.kz) runs from 12 April 2006 and offers more than 900 information services to citizens and businesses. While information services are sold on a portal in three languages: Kazakh, Russian and English. With the portal in Kazakhstan optimizes turnover information in the public service to citizens and organizations to solve the problem of completeness and integrity of information perception by citizens government action.

Web portal users are divided into two categories:

\section{Visitors}

People in this category can view all pages of the web portal, but do not have access to the personal pages.

\section{Registered users}

To gain access to the personal page it is necessary to register on the web portal. Personal page allows citizens to use e-mail services, scheduling, distribution, contacts, etc.

With the portal in Kazakhstan Optimization of Traffic Information in the public service to citizens and organizations to solve the problem of completeness and integrity of information perception by citizens government action.

Participants in the project web- portal of "electronic government" includes all public authorities, as well as a number of private companies providing services to citizens and business structures: "Kazakhstan Temir Joly", "Kazakhtelecom" and others. The portal provides information about the order of the civil service, the procedure for filing complaints to state authorities, and obtain a replacement identification documents, the procedure for legalization of natural and legal persons of money, property located on the territory of Kazakhstan and beyond, timetables all modes of transport, as well as on the registration of vehicles and driving licenses and more.

Web Portal - "e-government" is a practical mechanism for implementing the concept of public service provision on the principle of "one window". The main purpose of its creation was to provide a single point of access to electronic services of public authorities, based on the needs of citizens and business - structures.

In order to facilitate the search for the maximum and obtain the necessary information services offered to citizens rather curious principle of grouping: information services are grouped on the web - portal in accordance with the basic life cycle: childhood, education, youth, family, work, retirement and business - Business cycles: planning, discovery, liquidation. In addition to information services on the portal implemented a number of services : " E-mail ", " service " or a "service scheduling", "subscription service". Was implemented personal section - My Portal is designed for registered users where they can take advantage of e-mail services, contact information, scheduling virtual receptionist.

To take advantage of personal services, you must register at this as an identifier specifies a unique identification number, which is checked against the information stored in the national database "Individuals". 
The portal also exists as virtual receptionist service for receiving applications from citizens to public authorities. This service requires a means of digital signatures, which can be given to anyone interested citizen. Use of digital signature ensures the integrity and authorship of this request.

Another important task for the implementation of the project web - portal was the organization of quality service providing timely updating of information resources. For this was created by Editorial Board, which includes representatives of all public bodies have total knowledge about the activities of the public authority having jurisdiction and to collect and provide materials. Editorial Board on an ongoing basis is analyzing the functions of state agencies, the study of the current legislation, the events taking place in various spheres of life and publishes on the web portal.

How does the portal showed Internet dialogue with the President of Kazakhstan. Then he stood without technical problems load of 3.5 thousand users per second. Today the number of users of egovernment website reached seven thousand people.

\section{A sample set of e-government services}

This section describes the most relevant services EPO. List of electronic services is not complete, it is open to additions as needs of users and the willingness of government agencies to provide new services. In determining the list of electronic services should be developed classification system, which allows to make a phased plan for the future implementation services as well as to carry out their typing.

Formation and development of e government services

Informatization of public authorities with regard to the requirements of e-government plans to transition from reliance on intra need to focus on the needs and problems of citizens and organizations. Formation and implementation of $\mathrm{e}$ - government services will be part of the creation and development of departmental information systems.

Formation of e - government services will be carried out on the basis of a functional analysis of regulations for public services and the implementation of administrative processes. According to the results of the analysis is planned to develop proposals for the modernization of public administration and implementation of administrative procedures.

Within the framework of implementation of this direction will be determined by requirements for information systems of public bodies in the implementation of e-services and interaction with the basic components of e-government infrastructure.

At the initial stage of implementation of the program will be determined by regulation development, acceptance, support and development of public e-services, as well as the standard form of documentation.

Provision of e - government services involves making changes to existing departmental information systems or the development of new information systems with the standards for the integration of their interaction with the portal of e-government.

The Program on the basis of departmental information systems will be carried out implementation of e- services, including 85 types of services (70 and 15 interactive information.) Implementing transactional services will be carried out after the creation of "payment gateway" to interact with the banking system.

In accordance with the basic spheres of life of citizens and the functioning of organizations, a list of basic e-services according to the appendix to this program.

\section{References:}

1. Banisar, David (2011) "The right to Information and Privacy: Balancing Rights and Managing Conflicts". World Bank Institute Governance Working Paper (10 march, 2011).

2. (2001) Electronic Government. POST Report Summary, \#110, February 2001

3. (2004) Gosudarstvennaya programma formirovaniya «Elektronnogo pravitel'stva» V RK na 2005-2007, 10.11.2004.

4. O Andronova, A Nikolaev (2014) Elektronnoe pravitel'stvo v Evrope i mire. O. Andronova olga@ci.ru, A. Nikolaev, alnik@eureca.ru

5. Golobutskiy A, Shevchuk O (2014) "Elektronnoe pravitel'stvo"

6. (2014) Informatsionnye resursy Internet: Available: $\quad$ www.e.gov.kz, (Accessed: 12.12.2014).
7. (2014) Informatsionnye resursy Internet: Available: www.aic.gov.kz, (Accessed: 12.12.2014)

8. (2014) Informatsionnye resursy Internet: Available:

(Accessed: 12.12.2014)

9. (2014) Informatsionnye resursy Internet: Available: www.neweco.ru, (Accessed: 12.12.2014)

10. (2014) Informatsionnye resursy Internet: Available: www.e-russia.ru, (Accessed: 12.12.2014)

11. (2014) Informatsionnye resursy Internet: Available: www.e-rus.ru, (Accessed:

12.12.2014) 